\title{
ПОРУШЕННЯ МЕНСТРУАЛЬНОЇ ФУНКЦІЇ: СИТУАЦІЯ В СВІТІ I В УКРАЇНІ - У ЖІНОК РЕПРОДУКТИВНОГО ВІКУ ТА 3 НЕАТИПОВОЮ ГІПЕРПРОЛІФЕРАТИВНОЮ ПАТОЛОГІЄЮ ЕНДОМЕТРІЯ
}

\author{
${ }^{1}$ ДУ «Інститут педіатрії, акушерства і гінекології імені академіка О. М. Лук'янової НАМН України», \\ м. Київ, Україна \\ ${ }^{2}$ Національна медична академія післядипломної освіти імені П. Л. Шупика, м. Київ, Україна \\ ${ }^{3}$ ДУ «Інститут громадського здоров'я імені О. М. Марзєєва НАМН України», м. Київ, Україна
}

\begin{abstract}
Мета: вивчити особливості порушення менструального циклу (ПМЦ) в Україні у 2010-2017 рр. у жінок репродуктивного віку та з неатиповою гіперпролісреративною патологією ендометрія (НГПЕ).

Матеріали і методи. Використано дані статистичної звітності МОЗ України та Державної служби статистики України щодо жіночого населення віком 18-49 років. Вивчено особливості менструальної фрункції у 184 пацієнток із НГПЕ, поділених на три групи: I ( $n=60)$ - неатипова гіперплазія ендометрія (НГЕ), II (n=62) - поліпи тіла матки (ПТМ), III (n=62) - поєднання НГЕ+ПТМ.

Результати. Частота ПМЦ серед жінок України у 2010-2017 рр. становила 15,96 \%. Відзначено коливання значень показника від найнижчих у м. Севастополі (2,92 \%) та в Луганській області (5,90 \%о) до найвищих у Дніпропетровській області (26,16 \%) та в м. Києві (29,84 \%о). Встановлено, що чим більша поширеність ПМЦ, тим більша частота хвороб сечостатевої системи $(r=0,75)$ та деяких гінекологічних захворювань - сальпінгітів $(r=0,63)$, ендометріозу $(r=0,42)$. Найвищу частоту ПМЦ спостерігали у III $(61,3 \%)$ та в I $(53,3 \%)$ групах, і лише у третини (32,3\%) хворих II групи.

Висновки. 1. Найвищі показники порушення менструального циклу визначено у жінок з НГЕ та поєднанням НГЕ+ПТМ на відміну від пацієнток тільки з поліпами тіла матки.

2. ПМЦ можна розглядати як маркер та показник неблагополуччя фрункціонування сечостатевої системи та наявності гіперпроліферативного процесу ще на догоспітальному етапі.
\end{abstract}

КЛЮЧОВІ СЛОВА: порушення менструального циклу; гіперпроліферативна патологія ендометрія; поліп тіла матки; гіперплазія ендометрія.

Порушення менструальної фрункції $є$ однією із провідних патологій жіночої статевої сорери. Дослідники багатьох країн світу приділяють увагу пошуку сучасних критеріїв діагностики, тригерних чинників та оптимальних лікувальних концепцій.

Так, у процесі нещодавнього дворічного американського опитування було встановлено, що серед 20 млн відвідувань медичних закладів із приводу гінекологічних захворювань, 19,1 \% випадків були пов'язані 3 порушенням менструального циклу (ПМЦ), а аномальна маткова кровотеча $€$ причиною 25 \% гінекологічних операцій [3], яку у Великій Британії також вказують, як найбільш важливу причину гістеректомій [4]. Близько одного мільярда доларів на рік складають страхові виплати, що пов'язані з аномальною матковою кровотечею [1], яка корелює з низьким соціальноекономічним статусом, психологічним стресом та болями в животі [5].

Щодо країн сходу, проведене масштабне дослідження в Ірані встановило, що розповсюдженість первинної дисменореї склало 73,27 \% (95 \% ДI=65,12-81,42), менорагії - 19,24 \% (95 \%
Дl=12,78-25,69), гіперменореї - 12,94\% (95 \% Дl=9,31-16,57), а 6,04 \% жінок у цілому мали метрорагію (95 \% ДІ=1,99-10,08) [7]. У Пакистані найрозповсюдженішим ПМЦ виявилася поліменорея, яку спостерігали серед 30 \% жінок репродуктивного віку [2].

Мета роботи: вивчити особливості порушення менструального циклу в Україні у 2010-2017 рр. у жінок репродуктивного віку та 3 неатиповою гіперпроліферативною патологією ендометрія (НГПЕ).

Матеріали і методи. Для розуміння ситуації 3 ПМЦ на території України було проведено описове епідеміологічне дослідження суцільного типу 3 використанням статистичних даних за 20102017 рр. з поділом на чотирирічні періоди - 20102013 та 2014-2017 рр. За останні чотири роки зазнав деяких змін територіальний поділ України, зокрема, за рахунок окупації території АР Крим, Донецької та Луганської областей. Цей фракт був врахований як систематична помилка при аналізі та оцінці отриманих результатів на цих територіях. Дані про жінок із ПМЦ брали з відомчої 
статистичної звітності ДЗ «Центр медичної статистики МОЗ України», що видавалася у збірниках «Стан здоров'я жіночого населення в Україні» за 2010-2017 рр. Кількість жінок відповідного віку визначали за даними Державної служби статистики України. Фертильний вік у цьому дослідженні обмежувався періодом 18-49 років.

Оцінювали частоту патології в Україні та областях шляхом аналізу розрахунку поширеності (prevalence proportion), проведений кореляційний аналіз та розрахунок відношення ризику (ВР) виникнення патології у 2010-2013, 2014-2017 рр. і в 2014-2017 рр. порівняно з 2010-2013 рр. в Україні та у кожній окремій області для ПМЦ серед жінок фрертильного віку.

Результати щодо розрахунку ВР в областях були картовані, де ВР з урахуванням 95 \% довірчого інтервалу в кожній області позначали кольором: червоний - ВР перевищував 1 з ймовірністю 95 \%; блакитний - ВР менший від 13 ймовірністю 95 \%; білий - ВР не відрізнявся від 1 з ймовірністю $95 \%$.

Також вивчено особливості менструальної фрункції у пацієнток репродуктивного віку з неатиповою гіперпроліфреративною патологією ендометрія (НГПЕ). Обстежено 184 пацієнтки відділення планування сім'ї та оперативної реабілітації репродуктивної фрункції жінок ДУ «Інститут педіатрії, акушерства і гінекології імені академіка О. М. Лук'янової НАМН України» з діагнозом НГПЕ. Жінок поділено на три основні групи: I групу склали жінки з неатиповою гіперплазією ендометрія (НГЕ) (n=60); II групу - пацієнтки, у яких діагностували поліпи тіла матки (ПТМ) $(n=62)$; до III групи увійшли хворі з поєднаною НГПЕ (поліпи тіла матки та неатипова гіперплазія ендометрія $($ НГЕ)) $(n=62)$. Середній вік жінок I групи становив $(34,9 \pm 6,9)$ року, II групи - $(33,0 \pm 5,7)$ року, III групи $(34,0 \pm 6,2)$ року, що не виявило статистично значущої відмінності у групах дослідження $(p=0,52)$ та дозволило проводити зіставлення даних і подальший аналіз.

Результати дослідження та їх обговорення. Частота ПМЦ за 2010-2017 рр. дорівнювала 15,96 $\pm 0,01$ серед 1000 жінок фрертильного віку (рис. 1). У розрізі областей спостерігали десятикратне коливання значень показника - від найменшого у м. Севастополі $(2,92 \pm 0,09) \%$ та в Луганській області $(5,90 \pm 0,05)$ \% до найбільшого у Дніпропетровській області $(26,16 \pm 0,06) \%$ та м. Києві $(29,84 \pm 0,07)$ \%. Якщо не брати до уваги Луганську область та м. Севастополь, то різниця між найменшим і найбільшим значенням показника буде трикратною (найменше у Тернопільській області $(9,17 \pm 0,07) \%$.

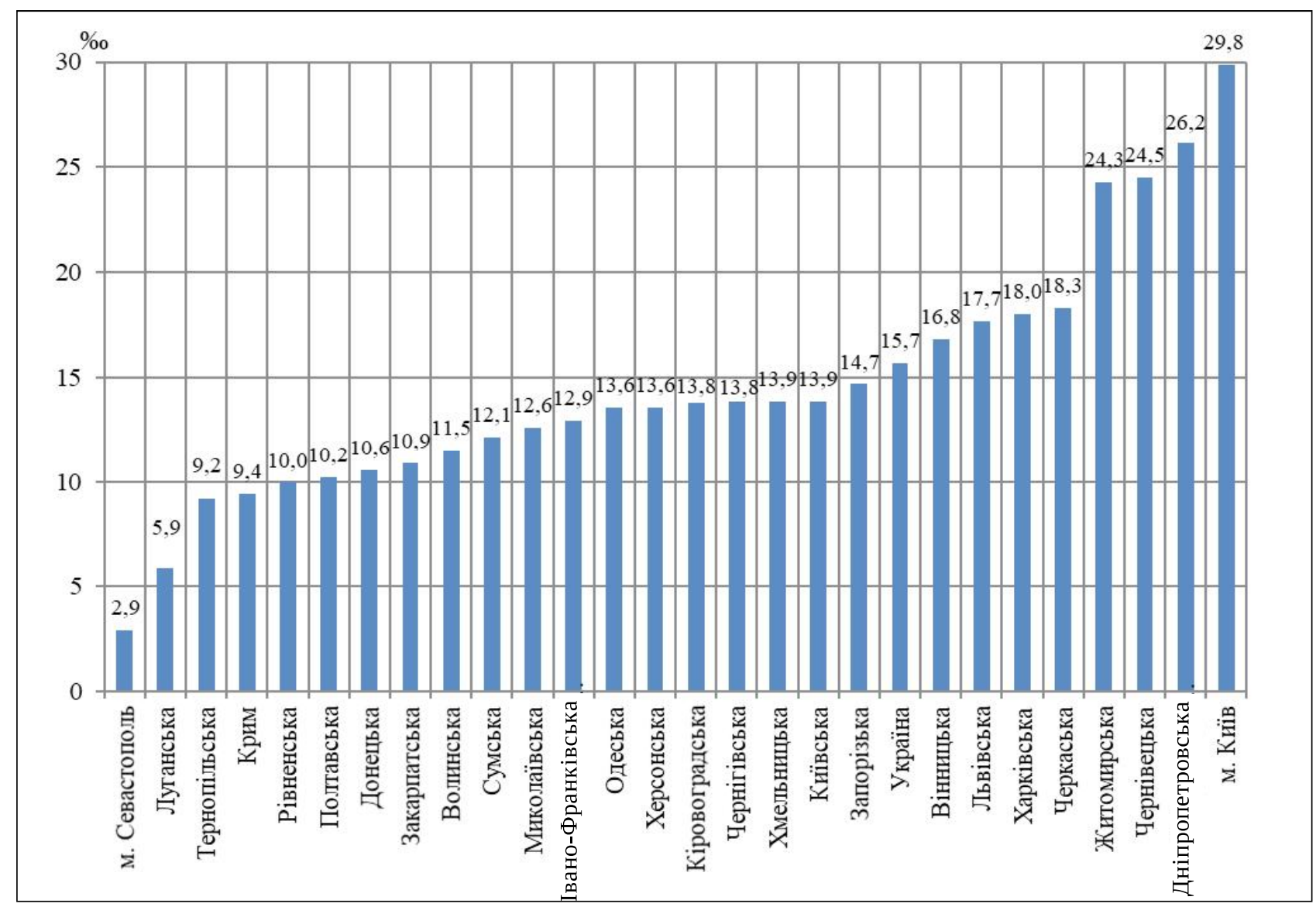

PUс. 1. Частота порушень менструального циклу серед жінок фертильного віку по областях України, 2010-2017 рр. (на 1000 жінок 18-49 років). 
За 2010-2013 рр. відносний ризик виникнення ПМЦ серед жінок фрертильного віку на території більшості областей був знижений порівняно
3 Україною загалом - м. Київ (ВР 2,06 [95 \% ДІ 2,04-2,07], p<0,05), м. Севастополь (ВР 0,19 [95 \% ДІ 0,18-0,20], p<0,05) (рис. 2).

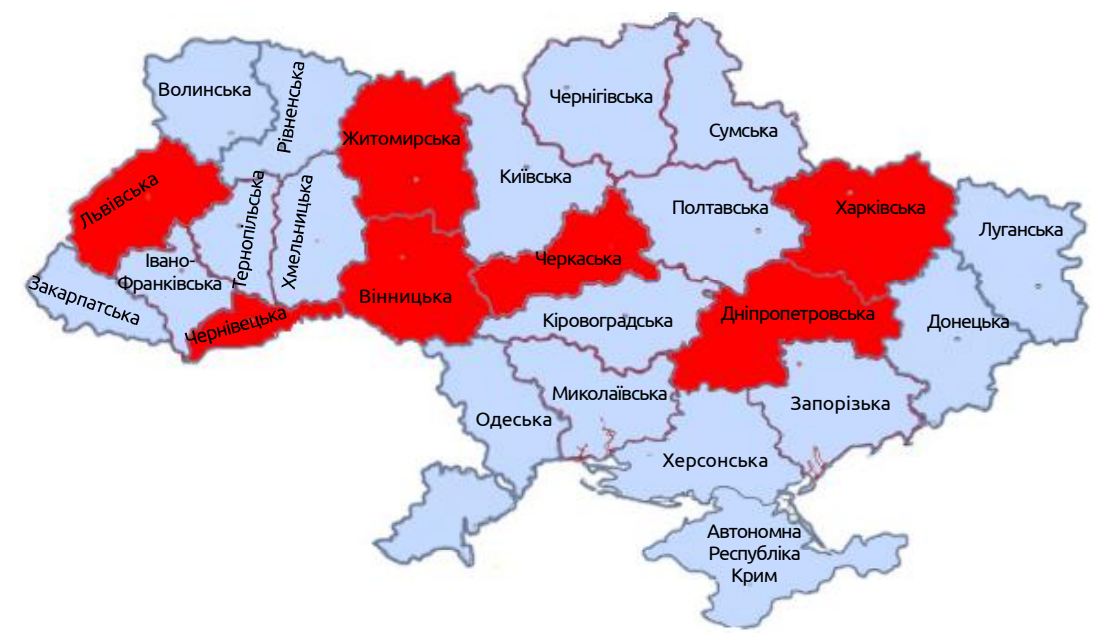

Puc. 2. Відносний ризик виникнення порушень менструального циклу серед жінок фертильного віку (18-49 років) в областях порівняно з Україною, 2010-2013 рр.

Найменші значення ВР спостерігали у м. Севастополі (ВР 0,19 [95 \% ДІ 0,18-0,20], p<0,05), Тернопільській (ВР 0,56 [95 \% ДІ 0,54-0,57], p<0,05), Полтавській (ВР 0,56 [95\% ДІ 0,55-0,57], p<0,05), Луганській (ВР 0,57 [95 \% ДІ 0,57-0,58], p<0,05), Рівненській (ВР 0,61 [95 \% ДІ 0,59-0,62], p<0,05) областях та АР Крим (ВР 0,60 [95 \% ДІ 0,59-0,60], p<0,05). У той же час на території семи областей (Вінницька (ВР 1,05 [95 \% ДІ 1,04-1,07], p<0,05), Харківська (ВР 1,12 [95 \% ДІ 1,11-1,13], p<0,05), Львівська (ВР 1,14 [95 \% Ді 1,13-1,15], p<0,05), Черкаська (ВР 1,26 [95 \% ДІ 1,24-1,28], $\mathrm{p}<0,05)$, Дніпропетровська (BP 1,49 [95 \% ДІ 1,48-1,50], p<0,05), Житомирська (ВР 1,56 [95 \% ДІ 1,54-1,57], p<0,05), Чернівецька (ВР 1,65 [95 \% ДІ 1,63-1,68], p<0,05) та м. Києва (ВР 2,06 [95 \% ДІ 2,04-2,07], p<0,05)) ВР був підвищений.

Територіальний поділ ВР виникнення ПМЦ серед жінок фрертильного віку в 2014-2017 рр. повторює такий за попередні чотири роки, а м. Київ зокрема (ВР 1,93 [95 \% ДІ 1,91-1,94], p<0,05) (рис. 3).

ВР виникнення ПМЦ серед жінок фертильного віку в 2014-2017 рр. порівняно 3 2010-2013 рр. в Україні (ВР 1,07 [95 \% ДІ 1,06-1,07], p<0,05) та м. Києві (ВР 1,00 [95 \% ДІ 0,99-1,01], p<0,05), як і на території більшості областей був підвищеним (рис. 4).

Найбільші значення підвищеного ВР спостерігали у Дніпропетровській (ВР 1,35 [95 \% ДІ 1,34-1,37], p<0,05), Полтавській (ВР 1,31 [95 \% ДІ 1,28-1,34], p<0,05), Івано-Франківській (ВР 1,20 [95 \% ДІ 1,17-1,23], p<0,05), Хмельницькій (ВР 1,19 [95 \% ДІ 1,16-1,21], p<0,05), Миколаївській (ВР 1,16 [95 \% ДІ 1,13-1,19], p<0,05) та Чернігівській (ВР 1,14 [95 \% ДІ 1,12-1,17], p<0,05) областях. Зниження ВР у 2014-2017 рр. порівняно 3 2010-2013 рр. було зафріксовано, окрім Луганської

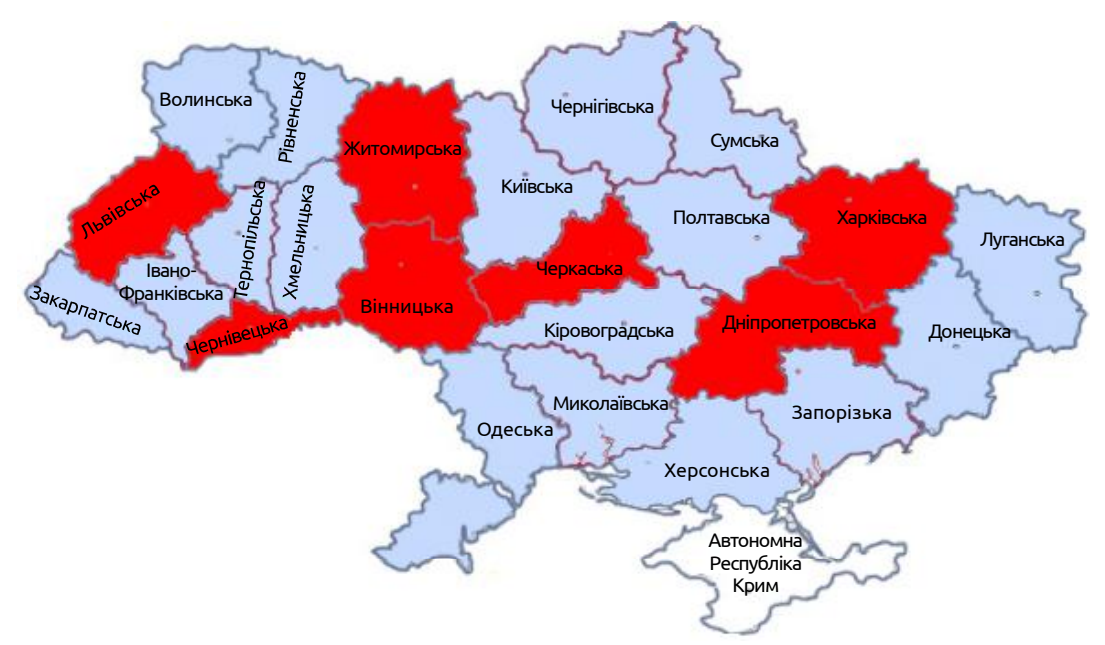

Puc. 3. Відносний ризик виникнення порушень менструального циклу серед жінок фертильного віку (18-49 років) в областях порівняно з Україною, 2014-2017 рр. 


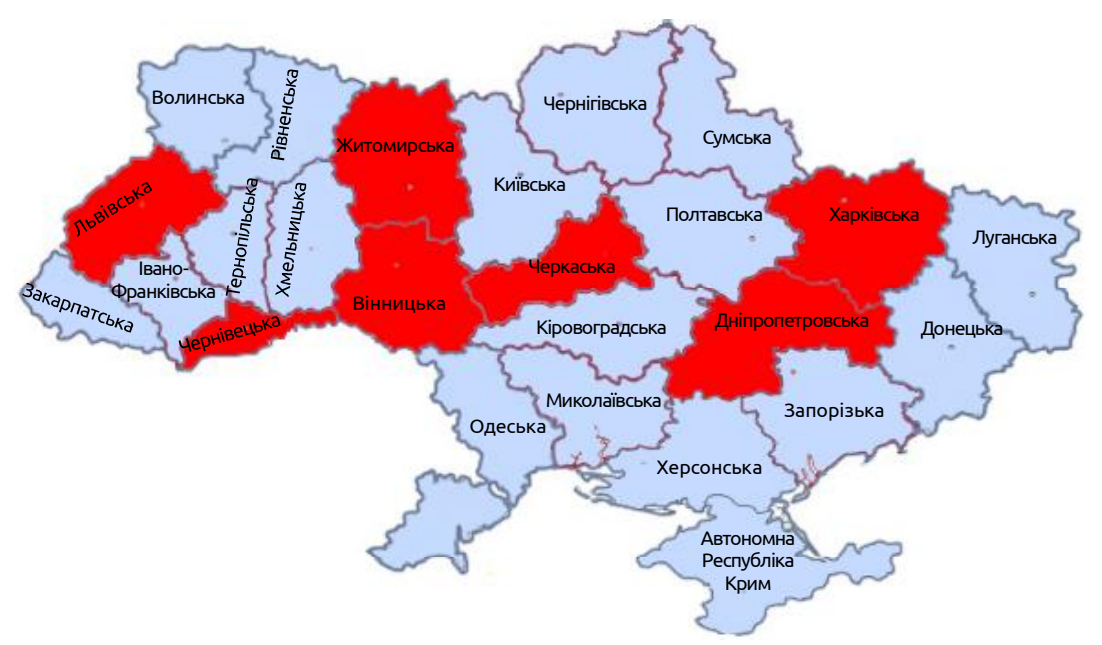

Puc. 4. Відносний ризик виникнення порушень менструального циклу серед жінок фертильного віку (18-49 років) в областях у 2014-2017 порівняно з 2010-2013 рр.

(ВР 0,26 [95 \% ДІ 0,26-0,27], p<0,05) та Донецької (ВР 0,35 [95\% ДІ 0,35-0,36], р<0,05) областей, у Черкаській (ВР 0,88 [95 \% ДІ 0,86-0,89], p<0,05), Закарпатській (ВР 0,89 [95 \% ДІ 0,87-0,91], p<0,05), Чернівецькій (ВР 0,93 [95 \% ДІ 0,91-0,95], р<0,05), Кіровоградській (ВР 0,94 [95 \% ДІ 0,920,97], p<0,05) областях. У м. Києві та Львівській області показник поширеності ПМЦ у жінок не змінився з плином часу.

У результаті аналізу встановлено: чим більша поширеність ПМЦ, тим більша частота хвороб сечостатевої системи та деяких гінекологічних захворювань. Підтвердженням цього $€$ розраховані коефіцієнти кореляції поширеності ПМЦ із частотою хвороб сечостатевої системи $(r=0,75, p<0,001)$, сальпінгітів $(r=0,63, p<0,001)$ та ендометріозу $(r=0,42, p<0,05)$. При цьому варто відзначити, що не зафріксовано кореляційного зв'язку між частотою виникнення досліджуваних патологічних станів та забезпеченістю населення лікарями акушер-гінекологами та їх атестацією.

Підсумовуючи результати розрахунку ВР виникнення ПМЦ 3 аналогічними розрахунками ВР виникнення сальпінгітів, ендометріозу та хвороб сечостатевої системи серед областей України у дев'яти спостерігали знижений ВР усіх вищезазначених патологічних станів (серед них Чернігівська і Полтавська області та п'ять західних областей - Волинська, Закарпатська, Рівненська, Тернопільська, Хмельницька, а також Луганська та Донецька області) та у п'яти (Дніпропетровська, Житомирська, Харківська, Черкаська та м. Київ) - підвищений. Саме в цих областях організатори охорони здоров'я повинні звернути увагу на цю проблему, адже серед останніх у Харківській, Черкаській областях та м. Києві ще й підвищений ВР виникнення раку тіла матки, а в Харківській області та м. Києві - ще й ВР виникнення смерті від нього.
Наступним блоком наукового дослідження $€$ вивчення особливостей менструальної функції у пацієнток репродуктивного віку з НГПЕ. При детальному аналізі поділу ПМЦ за її формами, показано, що найчастіше спостерігали нерегулярний цикл та менорагію $((11,96 \pm 2,39)$ і $(11,41 \pm 2,34) \%$ відповідно серед жінок з усіх трьох досліджуваних груп). При цьому при розгляді окремих груп відзначали тенденцію до збільшення частки жінок із нерегулярним циклом у групі НГЕ порівняно з групою жінок із поліпами тіла матки (18,3 проти $8,1 \%, p=0,16)$ та до збільшення частки жінок із менорагією у групі жінок з поєднаною НГПЕ на противагу групі з поліпами тіла матки (17,7 проти $6,5 \%, p=0,10$ ) (рис. 5). У інших випадках порівняння статистично значущої різниці не було відзначено.

Якщо ж підсумувати всі ПМЦ, то видно чітку різницю між групами досліджуваних жінок. Так, найбільшу частку ПМЦ спостерігали в жінок із поєднаною НГПЕ $(61,3 \pm 6,2) \%$ та у хворих, які мали морорологічні ознаки НГЕ $(53,3 \pm 6,4) \%$, в той час, як у пацієнток, в яких були верифіковані поліпи тіла матки, цей діагноз встановлено лише у третини $((32,3 \pm 5,9) \%, p=0,002$ та $p=0,03$ відповідно) випадків. Це можна розглядати як один із важливих клінічних маркерів наявності гіперпластичного процесу ендометрія навіть на догоспітальному етапі та за відсутності технічних можливостей проведення додаткових діагностичних методів.

На нашу думку, потрібно обов'язково зазначити, що під час вивчення менструальної фрункції у жінки будь-якого віку, лікарю акушер-гінекологу варто дотримуватися двох важливих правил: намагатися використовувати найбільш адаптивну як для пацієнта, так і для лікаря шкалу визначення змін менструальної функції та пам'ятати про високий рівень спорідненості розладів менструальної фрункції із патологічними змінами 


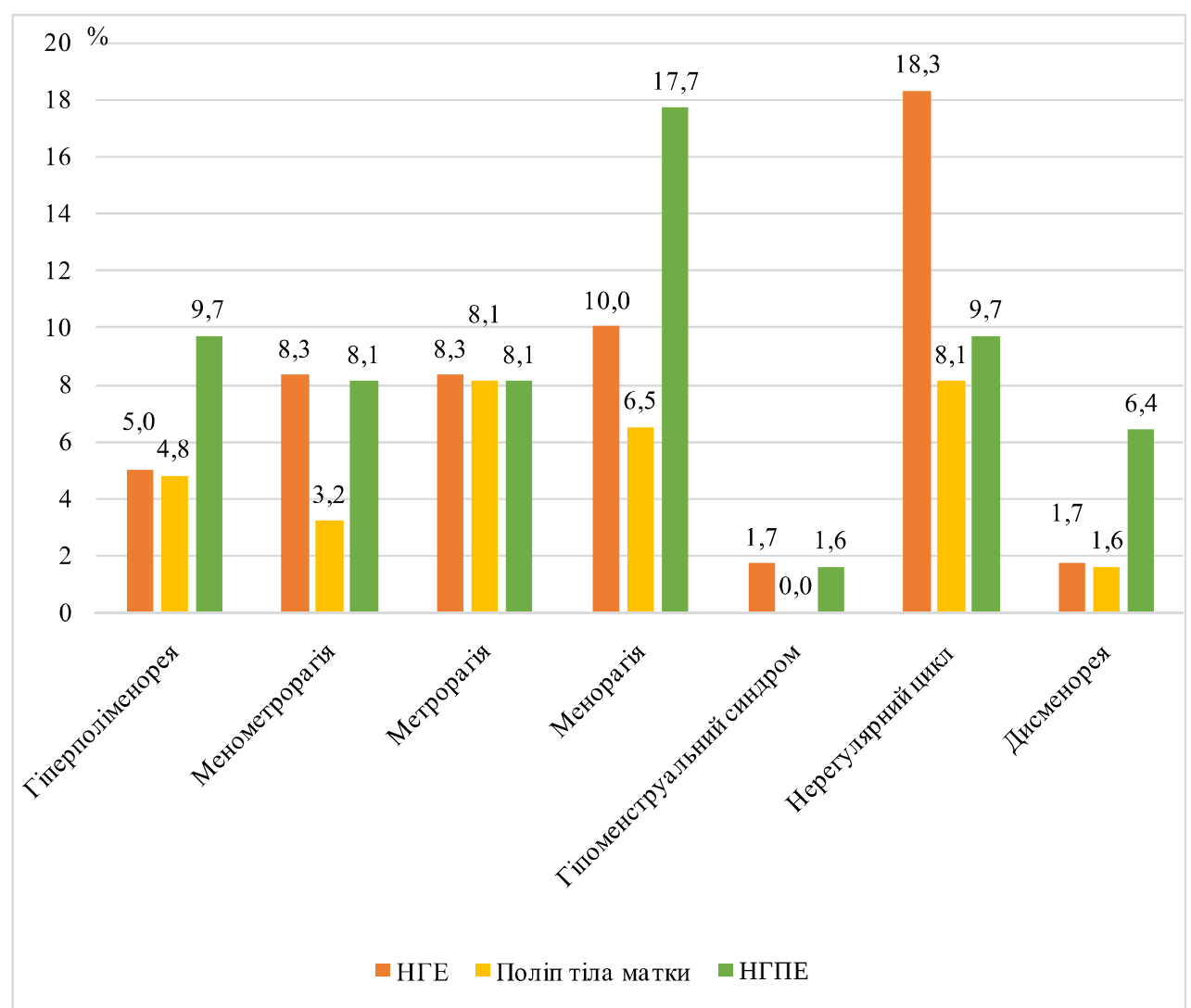

Рис. 5. Поділ порушень менструальної функції у жінок репродуктивного віку з неатиповою гіперпроліферативною патологією ендометрія, \%.

кровотворної системи, коли доцільним буде ведення пацієнтки разом із гематологом, особливо у підлітковому періоді [6].

\section{Висновки}

1. Встановлено, що частота ПМЦ серед жінок репродуктивного віку в Україні за 2010-2017 рр. склала $(15,96 \pm 0,01) \%$.

2. ПМЦ можна розглядати як важливий маркер та показник неблагополуччя у функціонуванні всієї сечостатевої системи ще на догоспітальному етапі, що кореляційними зв'язками відображено між поширеністю ПМЦ та зростанням частоти хвороб сечостатевої системи ( $r=0,75, p<0,001)$, сальпінгітів $(r=0,63, p<0,001)$ та ендометріозу $(r=0,42, p<0,05)$.
3. ПМЦ визначено у всіх групах жінок із неатиповою гіперпроліферативною патологією ендометрія, із найвищими показниками у жінок із поєднаною НГПЕ $(61,3 \pm 6,2) \%$ та у хворих із неатиповою гіперплазією ендометрія $(53,3 \pm 6,4) \%$ на противагу пацієнткам 3 поліпами тіла матки $((32,3 \pm 5,9) \%, p=0,002$ та $p=0,03$, відповідно).

Перспективи подальших наукових досліджень. Дослідження, виконані нами, продовжуються в плані зіставлення порушень менструального циклу як можливого маркера та показника розвитку гіперпроліферативної патології жіночої репродуктивної сорери, в тому числі ще на догоспітальному етапі.

\section{Список літератури}

1. A systematic review evaluating health-related quality of life, work impairment, and health-care costs and utilization in abnormal uterine bleeding / Z. Liu, Q. V. Doan, P. Blumenthal, R. W. Dubois // Value Health. - 2007. - Vol. 10 (3). P. 183-194.

2. Clinical pattern and spectrum of endometrial pathologies in patients with abnormal uterine bleeding in Pakistan: need to adopt a more conservative approach to treatment / M. Abid, A. A. Hashmi, B. Malik [et al.] // BMC Women's Health. 2014. - Vol. 14. - P. 132-139.

3. Providing quality family planning services: Recommendations of CDC and the US Office of Population Affairs / L. Gavin, S. Moskosky, M. Carter [et al.] // MMWR Recomm. Rep. - 2014. - Vol. 63. - P. 1-54.

4. Prevalence of heavy menstrual bleeding and experiences of affected women in a European patient survey /I. S. Fraser, D. Mansour, C. Breymann [et al.] // Int. J. Gynecol. Obstet. - 2015. - Vol. 128. - P. 196-200.

5. Quality of life and costs of levonorgestrel-releasing intrauterine system or hysterectomy in the treatment of menorrhagia: a 10-year randomized controlled trial / S. Heli vaara-Peippo, R. Hurskainen, J. Teperi [et al.] // Am. J. Obstet. Gynecol. 2013. - Vol. 209 (535). - P. e1-14.

6. Screening and Management of Bleeding Disorders in Adolescents With Heavy Menstrual Bleeding. ACOG COMMITTEE OPINION SUMMARY, No. 785. Obstetrics\&Gynecology: September. - 2019. - Vol. 134. - Issue 3. - P. 658-659. 
7. The prevalence of menstrual disorders in Iran: A systematic review and meta-analysis / R. Omani Samani, A. Almasi Hashiani, M. Razavi [et al.] // Int. J. Reprod. Biomed (Yazd). - 2018. - Vol. 16 (11). - P. 665-678.

\title{
References
}

1. Liu, Z., Doan, Q.V., Blumenthal, P., \& Dubois, R.W. (2007). A systematic review evaluating health-related quality of life, work impairment, and health-care costs and utilization in abnormal uterine bleeding. Value Health, 10 (3), $183-194$.

2. Abid, M., Hashmi, A.A., Malik, B., Haroon, S., Faridi, N., Edhi, M.M., \& Khan, M. (2014). Clinical pattern and spectrum of endometrial pathologies in patients with abnormal uterine bleeding in Pakistan: need to adopt a more conservative approach to treatment. BMC Women's Health, 14, 132-139.

3. Gavin, L., Moskosky, S., Carter, M., Curtis, K., Glass, E., Godfrey, E., et al. (2014). Providing quality family planning services: Recommendations of CDC and the US Office of Population Affairs. MMWR Recomm. Rep., 63, 1-54.

4. Fraser, I.S., Mansour, D., Breymann, C., Hoffman, C., Mezzacasa, A., \& Petraglia, F. (2015). Prevalence of heavy menstrual bleeding and experiences of affected women in a European patient survey. Int. J. Gynecol. Obstet., 128, 196-200.

5. Heli vaara-Peippo, S., Hurskainen, R., Teperi, J., Aalto, A.M., Grénman, S., Halmesmäki, K., ... \& Paavonen, J. (2013). Quality of life and costs of levonorgestrel-releasing intrauterine system or hysterectomy in the treatment of menorrhagia: a 10-year randomized controlled trial. Am. J. Obstet. Gynecol., 209, 535, e1-14.

6. ACOG COMMITTEE OPINION SUMMARY, 785. (2019). Screening and Management of Bleeding Disorders in Adolescents With Heavy Menstrual Bleeding. Obstetrics \& Gynecology, 134 (3), 658-659.

7. Omani Samani, R., Almasi Hashiani, A., Razavi, M., Vesali, S., Rezaeinejad, M., Maroufizadeh, S., \& Sepidarkish, M. (2018). The prevalence of menstrual disorders in Iran: A systematic review and meta-analysis. Int. J. Reprod. Biomed. (Yazd), 16 (11), 665-678.

\section{НАРУШЕНИЯ МЕНСТРУАЛЬНОЙ ФУНКЦИИ: СИТУАЦИЯ В МИРЕ И В УКРАИНЕ - У ЖЕНЩИН РЕПРОДУКТИВНОГО ВОЗРАСТА И С НЕАТИПИЧЕСКОЙ ГИПЕРПРОЛИФЕРАТИВНОЙ ПАТО- ЛОГИЕЙ ЭНДОМЕТРИЯ}

Н. Е. Горбань' И. Б. Вовк ${ }^{1}$, Н. Г. Гойда ${ }^{2}$, О. В. Линчак ${ }^{3}$

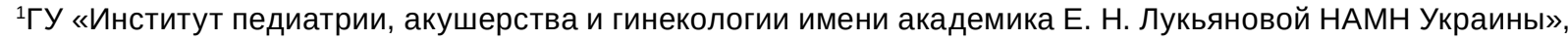
г. Киев, Украина

${ }^{2}$ Национальная медицинская академия последипломного образования имени П. Л. Шупика, г. Киев, Украина

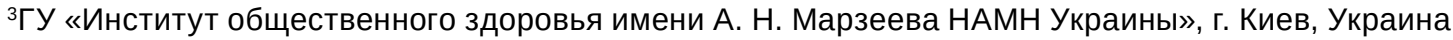

Цель: изучить особенности нарушения менструального цикла (НМЦ) в Украине в 2010-2017 гг. у женщин репродуктивного возраста и с неатипической гиперпролиферативной патологией эндометрия (НГПЭ).

Материалы и методы. Использованы данные статистической отчетности Минздрава Украины и Государственной службы статистики Украины о женском населении в возрасте 18-49 лет. Изучены особенности менструальной фрункции у 184 пациенток с НГПЭ, разделенных на три группы: I (n=60) - неатипическая гиперплазия эндометрия (НГЭ), II (n=62) - полипы тела матки (ПТМ), III (n=62) - сочетание НГЭ+ПТМ.

Результаты. Частота НМЦ среди женщин Украины в 2010-2017 гг. составляла 15,96 \%о. Отмечены колебания значений показателя от самых низких в г. Севастополе $(2,92 \%)$ и в Луганской области (5,90 \%о) до наивысших в Днепропетровской области $(26,16 \%)$ и в г. Киеве $(29,84 \%$ \%). Установлено, что чем выше распространенность НМЦ, тем выше частота болезней мочеполовой системы $(r=0,75)$ и некоторых гинекологических заболеваний - сальпингитов $(r=0,63)$ и эндометриоза $(r=0,42)$. Наивысшую частоту НМЦ наблюдали в III (61,3 \%) и в I (53,3 \%) группах, и только у трети (32,3 \%) больных II группы.

Выводы. 1. Самые высокие показатели нарушения менструального цикла выявлены у женщин с НГЭ и сочетанием НГЭ+ПтМ в отличии от пациенток только с полипами тела матки.

2. НМЦ можна рассматривать как маркер и показатель неблагополучия функционирования мочеполовой системы и наличия гиперпролиферативного процесса еще на догоспитальном этапе.

КЛЮЧЕВЫЕ СЛОВА: нарушение менструального цикла; гиперпролиферативная патология эндометрия; полип тела матки; гиперплазия эндометрия.

\author{
MENSTRUAL DYSFUNCTION: THE SITUATION IN THE WORLD AND IN UKRAINE - IN WOMEN OF \\ REPRODUCTIVE AGE AND WITH ATYPICAL HYPERPROLIFERATIVE PATHOLOGY OF THE ENDO- \\ METRIUM \\ N. Ye. Gorban', I. B. Vovk , N. H. Hoida 2 , O. V. Linchak ${ }^{3}$ \\ ${ }^{1}$ O. Lukianova Institute of Pediatrics, Obstetrics and Gynecology of NAMS of Ukraine, Kyiv, Ukraine \\ ${ }^{2} \mathrm{P}$. Shupyk National Medical Academy of Postgraduate Education, Kyiv, Ukraine \\ ${ }^{3} \mathrm{O}$. Marzieiev Institute of Public Health of NAMS of Ukraine, Kyiv, Ukraine
}

Purpose: investigation of menstrual dysfunction (MD) features in Ukraine in 2010-2017 and in the patients examined at the clinic. 
Materials and Methods. The materials of the statistical reports of the Ministry of Health of Ukraine and the State Statistics Service of Ukraine for the female population aged 18-49 were used. The peculiarities of menstrual function in 184 patients with non-atypical endometrial hyperproliferative pathology (NAEHP) were studied, divided into 3 groups: I $(n=60)$ - non-atypical endometrial hyperplasia $(N A E H)$, II $(n=62)$ - uterine body polyps (UBP), III $(n=62)$ is a combination of NAEN + UBP.

Results. The frequency of MD among women in Ukraine in 2010-2017 was $15.96 \%$. The fluctuations of the values of the indicator from the lowest in the city of Sevastopol (2.92\%) and in the Luhansk region (5.90\%) are noted to the highest in Dnipropetrovsk region $(26.16 \%)$ and Kyiv (29.84\%). It was found that the higher the prevalence of MD, the higher the incidence of diseases of the genitourinary system $(r=0.75)$ and some gynecological diseases - salpingitis $(r=0.63)$ and endometriosis $(r=0.42)$. The highest incidence of MD was found in group III (61.3\%) and group I (53.3\%), but only in a third (32.3\%) of patients in group II.

Conclusions. 1. The highest MD rates were found in women with NAEN and the combination of NAEN + UBP unlike patients with UBP only. 2. MD can be considered as a marker and indicator of poor functioning of the genitourinary system and the presence of a hyperproliferative process at the pre-hospital stage.

KEY WORDS: menstrual dysfunction; endometrial hyperproliferative pathology; uterine body polyp; endometrial hyperplasia.

Рукопис надійшов до редакції 29.08.2019 р.

Відомості про авторів;

Горбань Наталія Євгенівна - кандидат медичних наук, старший науковий співробітник відділення планування сім'ї ДУ «Інститут педіатрії, акушерства і гінекології імені академіка О. М. Лук'янової НАМН України»; тел.: +38(044) 483-84-23.

Вовк Іраїда Борисівна - доктор медичних наук, професор, завідувач відділення планування сім'ї дУ «Інститут педіатрії, акушерства і гінекології імені академіка О. М. Лук'янової НАМН України»; тел.: +38(044) 483-84-23.

Гойда Ніна Григорівна - доктор медичних наук, професор кафедри управління охороною здоров'я Національної медичної академії післядипломної освіти імені П. Л. Шупика; тел.: +38(044) 205-49-46.

Линчак Оксана Василівна - доктор медичних наук, провідний науковий співробітник лабораторії епідеміологічних досліджень і медичної інорорматики дУ «Інститут громадського здоров'я імені О. М. Марзєєва НАМН України»; тел.: +38(044) 292-06-29. 